\title{
IKLIM MIKRO DAN PRODUKTIVITAS PERKEBUNAN KOPI ROBUSTA (CAFEA ROBUSTA) DI KECAMATAN PUPUAN
}

\author{
I Komang Alit Aridana ${ }^{1}$, I Gede Astra Wesnawa ${ }^{2 *}$
}

Prodi Pendidikan Geografi, Universitas Pendidikan Ganesha, Indonesia

\section{A R T I C L E I N F O \\ Article history: \\ Received 13 Agustus 2018 \\ Received in revised form \\ 10 November 2018 \\ Accepted 12 November \\ 2018 \\ Available online 30 \\ November 2018}

Kata kunci; Kopi Robusta, Kecamatan Pupuan, dan Iklim Mikro

Keywords; Robusta Coffee, Pupuan Sub district, and Micro Climate

Analisis data yang di pengumpulan data menggunakan observasi dan pencatatan dokumen. perbedaan.

\section{A B S T R A C T}

Climate is one of the components that can affect life on earth such as human, animal and plant. The climate is closely related to the phenomenon of El-nino and La-nina. Robusta coffee is one type of the plants which is widely cultivated as a plantation crop. The cultivation of coffee plants is highly dependent on the climatic conditions in an area. This study aims (1) To know the distribution of Micro Climate situation in Pupuan Sub district (2) To know the distribution of Robusta coffee productivity in Pupuan District. (3) To analyze differences of micro climate condition and productivity Robusta coffee based on altitude of place in Pupuan Sub district. This research is done in Pupuan Sub district, Tabanan Regency. This research is a descriptive research with data collection method using observation method and document recording. The analysis of data which is used is descriptive quantitative by using t-test to find the difference.

Copyright (c) Universitas Pendidikan Ganesha. All rights reserved.

\footnotetext{
* Corresponding author.

E-mail addresses: alit.aridana@undiksha.ac.id, astra.wesnawa@undiksha.ac.id
} 


\section{Pendahuluan}

Pertanian merupakan suatu kegiatan manusia dalam memanfaatkan lingkungan di sekitarnya guna memenuhi kebutuhan hidup manusia. Pertanian merupakan salah satu jenis kegiatan dalam bidang produksi yang dihasilkan oleh tanaman dan hewan. pertanian memiliki dua makna yaitu secara sempit, pertanian adalah kegiatan bercocok tanam dan secara luas, pertanian adalah segala aktivitas manuasi yang berkaitan dengan bercocoktanam, perikanan, kehutanan, peternakan dan perkebunan. Pertanian sangat dipengaruhi oleh faktor geografis untuk menentukan usaha tani yang akan dikembangkan (Banowati \& Sriyanto, 2013). Berdasarkan lahannya pertanian dapat dibedakan menjadi dua yaitu lahan basah dan lahan kering, lahan basah terdiri atas perikanan dan persawahan dan lahan kering terdiri atas tegalan, pekarangan, ladang dan peternakan (Sriartha, 2000).

Klasifikasi pertanian terpadu yang menggunakan unsur-unsur: lereng, ketinggian, luas usaha, alat, arah usaha, dan tanaman. Berdasarkan ketinggian tempat, suhu menentukan jenis tanaman yang bisa tumbuh. Berdasarkan ketinggian, pertanian dapat diklasifikasikan menjadi tiga golongan yaitu; usahatani di dataran tinggi di atas 1000 meter, usahatani dataran tengah antara 500-1000 meter dan usahatani dataran rendah dibawah 500 meter (Sriartha, 2000).

Selain terkenal sebagai "lumbung beras", Kabupaten Tabanan juga terkenal dengan hasil perkebunannya salah satunya adalah tanaman kopi. Kopi merupakan salah satu komoditas unggulan dari 40 komoditas unggulan nasional dan termasuk kom oditas unggulan utama di Provinsi Bali (Priantara, 2016). Hal ini karena kopi telah memberikan sumbangan yang cukup besar bagi devisa negara, menjadi ekspor non migas, selain itu dapat menjadi penyedia lapangan kerja dan sumber pendapatan bagi petani pekebun kopi maupun bagi pelaku ekonomi lainnya yang terlibat dalam budidaya, pengolahan, maupun dalam mata rantai pemasaran (Thamrin, 2015). Tanaman kopi yang banyak di kembangkan adalah kopi Robusta. Kecamatan Pupuan merupakan daerah yang sangat potensial untuk dikembangkan dalam bidang pertanian kopi Robusta. Sebagian besar pekerjaan masyarakat di Kecamatan Pupuan di sektor pertanian khususnya sebagai petani kopi. Kopi Robusta yang dihasilkan di Kecamatan Pupuan sudah diekspor ke luar daerah tidak hanya di Bali saja namun sudah ada Negara yang menjadi tujuan ekspor yaitu Korea.

Hasil ekspor Kopi Robusta yang dilakukan tidak secara langsung berdampak pada petani kopi dikarenakan jumlah produksi Kopi Robusta di Kecamatan Pupuan selalu mengalami fluktuasi. Kepala Bidang Perkebunan Dinas Pertanian Tabanan, mengatakan pada panen tahun lalu biasanya dalam satu "gembon" tumbuh setidaknya 40 hingga 50 buah kopi dan tahun ini hanya tumbuh 20 buah kopi dalam satu tangkai. Meski terjadi penurunan setidaknya 50 persen dibandingkan tahun lalu. Tjasyono (2004) menyatakan bahwa iklim mikro merupakan variasi iklim yang meliputi wilayah yang lebih spesifik, iklim ini penting bagi kehidupan manusia, tumbuhan dan hewan, karena kondisi udara pada skala mikro ini yang akan berkontak langsung dengan manusia dan hewan maupun tanaman dalam pertanian iklim memiliki peranan yang besar dikarenakan memberikan pengaruh pada pertumbuhan tanaman hingga menentukan hasil produksi pada tanaman.

Penelitian yang serupa juga sudah pernah dilakukan oleh peneliti lain yaitu oleh Prasetyo, Aini, \& Maghfoer (2017) dengan judul Dampak Perubahan Iklim Terhadap Produktivitas Kopi Robusta (Caffea Robusta) di Kabupaten Malang. Yang ke dua penelitian yang dilakuan oleh Supriadi (2014) dengan judul Budidaya Tanaman Kopi Untuk Adaptasi Dan Mitigasi Perubahan Iklim. Untuk mengetahui pengaruh iklim mikro 
terhadap produktivitas tanaman Kopi Robusta di Kecamatan Pupuan diperlukannya penelitian guna mengetahui pengaruh yang ditimbulkan oleh adanya iklim mikro terhadap produktivitas pertanian kopi Robusta. Maka dari itu perlu dilakukan penelitian mengenai "Iklim Mikro dan Produktivitas Perkebunan Kopi Robusta (Caffea Robusta) Di Kecamatan Pupuan.

\section{Metode}

Metode observasi digunakan dalam untuk mengumpulkan data dari dinas-dinas dan instansi-instansi terkait yang menjadi sumber informasi yaitu, Dinas Pertanian data yang di cari adalah hasil panen Kopi Robusta dan data curah hujan, Kantor Camat Pupuan data yang di cari adalah profil Kecamtan Pupuan. Pencatatan dokumen Metode ini digunakan untuk mencatat semua dokumen yang berhubungan dengan penelitian ini adapun data yang dicatat adalah fisiografis Kecamatan Pupuan, data suhu, curah hujan, kelembaban dan produksi pertanian kopi. Analisis data yang digunakan adalah deskriptif kuantitatif dengan pendekatan geograf yang digunakan adalah Pendekatan Keruangan, analisis ini digunakan agar data - data yang berupa angka dapat dideskripsikan atau dijelaskan. Analisis kuantitatif atau statistik dengan menggunakan perhitungan. Analisis t-tes (Astawa, 2011).

$$
t=\frac{X_{1}-X_{2}}{\sqrt{\frac{S d_{1}^{2}}{n_{2}}}+\frac{S d_{2}^{2}}{n_{2}}-2 r\left(\frac{S d_{1}}{\sqrt{n_{1}}}\right)\left(\frac{S d_{2}}{\sqrt{n_{2}}}\right)}
$$

\section{Hasil Dan Pembahasan}

\subsection{Distribusi Iklim Mikro di Kecamatan pupuan}

Tabel 1

Sebaran Iklim Mikro Berdasarkan Kelas Interval Ketinggian Tempat

\begin{tabular}{|c|c|c|}
\hline Ketinggian Tempat & Iklim Junghun & Iklim Oldeman \\
\hline $428-628$ & $\begin{array}{l}\text { Iklim Panas/ Tropis } \\
\text { Suhu Udara (24), Kelembaban Udara (84) } \\
\text { dan Curah Hujan (261). }\end{array}$ & $\begin{array}{l}\text { Tipe iklim B2. Bulan basah sebanyak } 8 \\
\text { bulan dan bulan kering } 2-3 \text { bulan }\end{array}$ \\
\hline $700-800$ & $\begin{array}{c}\text { Iklim Sedang } \\
\text { Suhu Udara (23), Kelembaban Udara (85) } \\
\text { dan Curah Hujan (271) }\end{array}$ & $\begin{array}{l}\text { Tipe iklim B2. Bulan basah sebanyak } 8 \\
\text { bulan dan bulan kering } 2-3 \text { bulan }\end{array}$ \\
\hline
\end{tabular}




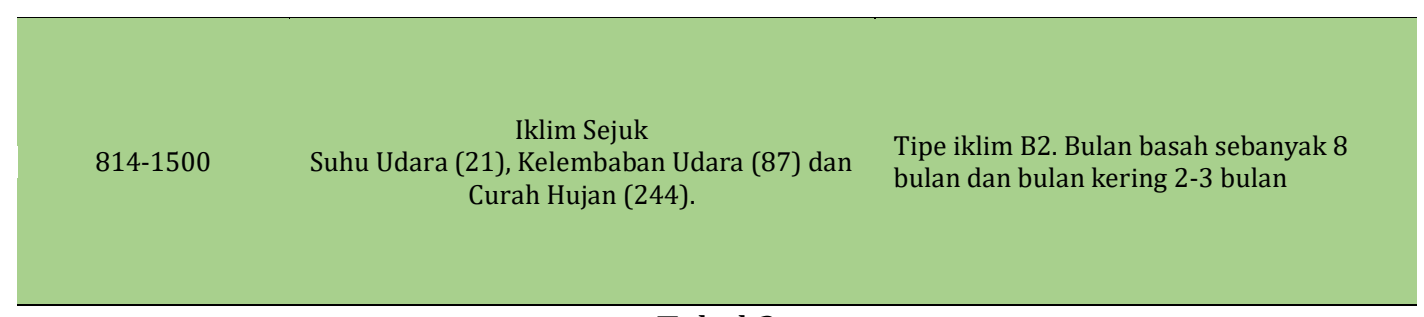

Tabel 2

Sebaran Iklim Mikro Berdasarkan Kelas Interval Ketinggian Tempat

\begin{tabular}{|c|c|c|c|c|}
\hline $\begin{array}{l}\text { Ketinggian Tempat } \\
\text { (Meter diatas } \\
\text { permukaan laut.) }\end{array}$ & Desa & $\begin{array}{c}\text { Rata-Rara } \\
\text { Suhu Udara } \\
\quad\left(\mathrm{C}^{0}\right)\end{array}$ & $\begin{array}{c}\text { Rata-Rata } \\
\text { Kelembaban } \\
\text { Udara } \\
(\%)\end{array}$ & $\begin{array}{l}\text { Rata-Rata } \\
\text { Curah Hujan } \\
\text { (mm) }\end{array}$ \\
\hline \multirow{5}{*}{$428-628$} & Sai & \multirow{5}{*}{24} & \multirow{5}{*}{84} & \multirow{5}{*}{261} \\
\hline & Belimbing & & & \\
\hline & Karya Sari & & & \\
\hline & Pupuan & & & \\
\hline & Bantiran & & & \\
\hline \multirow{5}{*}{$700-800$} & Padangan & \multirow{5}{*}{23} & \multirow{5}{*}{85} & \multirow{5}{*}{271} \\
\hline & Jelijih Punggang & & & \\
\hline & Kebon Padangan & & & \\
\hline & Munduk Temu & & & \\
\hline & Desa Pajahan & & & \\
\hline \multirow{4}{*}{$814-1500$} & Batungsel & \multirow{4}{*}{21} & \multirow{4}{*}{87} & \multirow{4}{*}{240} \\
\hline & Belatungan & & & \\
\hline & Sanda & & & \\
\hline & Pujungan & & & \\
\hline
\end{tabular}

Berdasarkan klasifikasi iklim menurut Junghun dan Oldeman pada Tabel 01, iklim mikro di Kecamatan Pupuan terbagi menjadi tiga jenis iklim yaitu iklim Panas/Tropis, Iklim Sedang dan Iklim Sejuk deng tipe iklim B2 keadaan bulan basah selama delapan bulan berturut-turut dan bulan kering dua sampai tiga bulan berturutturut. Distribusi dari iklim mikro di Kecamatan Pupuan dapat dijelaskan memalui Tabel 02. pada Tabel tersebut, distribusi atau keadaan iklim mikro berdasarkan ketinggian tempat, pada ketinggian tempat 428-628 meter diatas permukaan laut, dengan keadaan iklim mikro rata-rata Suhu udara $\left(24 \mathrm{C}^{\circ}\right)$, Kelembaban udara (84\%) dengan curah hujan (261 mm) pertahunnya. Pada ketinggian 700-800 meter diatas permukaan laut, keadaan iklim mikro rata-rata Suhu udara $\left(23 \mathrm{C}^{\circ}\right)$, Kelembabanudara (85\%), Curah hujan (271 $\mathrm{mm}$ ) pertahunya dan pada ketinggian 814-1500 meter diatas permukaan laut, keadaan iklim mikro rata-rata Suhu udara $\left(21 \mathrm{C}^{0}\right)$, Kelembabanudara (87 \%), Curah Hujan (240 $\mathrm{mm}$ ) pertahunya. 


\subsection{Distribusi Produktivitas Perkebunan Kopi Robuista}

Tabel 3. Produktivutas Perkebunanan Kopi Robusta (Kg/Ha)

Berdasarkan Ketinggian Tempat Di Kecamatan Pupuan 2008-2017

\begin{tabular}{|c|c|c|c|c|}
\hline Kelas Interval & Desa & produktivitas & $\begin{array}{l}\text { produktivitas } \\
\text { Rata }\end{array}$ & Rata- \\
\hline \multirow{5}{*}{$428-628$} & Desa sai & 520 & \multirow{5}{*}{560} & \\
\hline & Desa Belimbing & 586 & & \\
\hline & Desa Karya Sari & 612 & & \\
\hline & Desa Pupuan & 617 & & \\
\hline & Desa Bantiran & 464 & & \\
\hline \multirow{5}{*}{$700-800$} & Desa Padangan & 544 & \multirow{5}{*}{467} & \\
\hline & Desa Jelijih Punggang & 324 & & \\
\hline & Desa Kebon Padangan & 446 & & \\
\hline & Desa Munduk Temu & 488 & & \\
\hline & Desa Pajahan & 536 & & \\
\hline \multirow{4}{*}{$814-1500$} & batungsel & 496 & \multirow{4}{*}{513} & \\
\hline & Desa Belatungan & 519 & & \\
\hline & Desa Sanda & 524 & & \\
\hline & Desa Pujungan & 511 & & \\
\hline
\end{tabular}

Distribusi distribusi produktivitas Kopi Robusta di Kecamatan Pupuan pada kelas interval kedua dengan ketinggian 700-800 meter diatas permukaan laut memiliki produktivitas rata-rata $467 \mathrm{Kg} / \mathrm{Ha}$, dengan sebaran Desa Padangan (ketinggian, 800 meter diatas permukaan laut, produktivitas $544 \mathrm{Kg} / \mathrm{Ha}$ ), Desa Padangan (ketinggian, 800 meter diatas permukaan laut, produktivitas $544 \mathrm{Kg} / \mathrm{Ha}$ ), Desa Jelijih Punggang (ketinggian 725 meter diatas permukaan laut, produktivitas $324 \mathrm{Kg} / \mathrm{Ha}$ ), Desa Kebon Padangan (ketinggian, 700 meter diatas permukaan laut, produktivitas $446 \mathrm{Kg} / \mathrm{Ha}$ ), Desa Munduk Temu (ketinggian, 700 meter diatas permukaan laut, produktivitas 488 $\mathrm{Kg} / \mathrm{Ha}$ ), dan Desa Pajajahan (ketinggian, 700 meter diatas permukaan laut, produktivitas $536 \mathrm{Kg} / \mathrm{Ha}$ ).

Distribusi produktivitas Kopi Robusta di Kecamatan Pupuan pada kelas interval ketiga dengan ketinggian 814 - 1500 meter diatas permukaan laut memiliki produktivitas rata $513 \mathrm{Kg} / \mathrm{Ha}$, dengan sebaran Desa Batungsel (ketinggian 814 meter diatas permukaan laut memiliki produktivitas $496 \mathrm{Kg} / \mathrm{Ha}$ ), Desa Belatungan (ketinggian 1000 meter diatas permukaan laut, produktivitas $519 \mathrm{Kg} / \mathrm{Ha}$ ), Desa Sanda 
(ketinggian 1000 meter diatas permukaan laut, produktivitas $524 \mathrm{Kg} / \mathrm{Ha}$ ), dan Desa Pujungan (ketinggian 1500meter diatas permukaan laut, produktivitas $511 \mathrm{Kg} / \mathrm{Ha}$ ).

\subsection{Perbedaan Iklim Mikro dan Produktivitas Perkebunan Kopi Robusta}

Tabel 4.

Data Produktivitas, Suhu Udara, Kelembabandan Curah Hujan.

\begin{tabular}{|c|c|c|c|c|c|c|}
\hline $\begin{array}{c}\text { Ketinggian } \\
\text { Tempat } \\
\text { (Meter } \\
\text { diatas } \\
\text { permukaan } \\
\text { laut) } \\
\end{array}$ & Desa & $\begin{array}{l}\text { Jumlah } \\
\text { Sampel }\end{array}$ & $\begin{array}{l}\text { Produktivitas } \\
(\mathrm{Kh} / \mathrm{Ha})\end{array}$ & $\begin{array}{c}\text { Suhu } \\
\text { Udara } \\
\left(\mathrm{C}^{0}\right)\end{array}$ & $\begin{array}{c}\text { kelembaban } \\
\text { Udara } \\
(\%)\end{array}$ & $\begin{array}{l}\text { Curah } \\
\text { Hujan } \\
\text { (mm) }\end{array}$ \\
\hline \multirow{10}{*}{$428-628$} & \multirow{2}{*}{ Bantiran } & \multirow{2}{*}{2} & 297 & 23 & 84 & 244 \\
\hline & & & 298 & 24 & 84 & 244 \\
\hline & \multirow{2}{*}{ Pupuan } & \multirow{2}{*}{2} & 312 & 24 & 84 & 244 \\
\hline & & & 295 & 24 & 84 & 244 \\
\hline & \multirow{2}{*}{ Blimbing } & \multirow{2}{*}{2} & 272 & 23 & 85 & 283 \\
\hline & & & 320 & 24 & 85 & 264 \\
\hline & \multirow{2}{*}{ Karya sari } & \multirow{2}{*}{2} & 211 & 23 & 85 & 264 \\
\hline & & & 364 & 24 & 85 & 264 \\
\hline & \multirow{2}{*}{ Desa Sai } & \multirow{2}{*}{2} & 436 & 23 & 85 & 244 \\
\hline & & & 361 & 23 & 85 & 244 \\
\hline \multirow{11}{*}{$700-800$} & \multirow{2}{*}{ pajahan } & \multirow{2}{*}{2} & 316 & 23 & 86 & 264 \\
\hline & & & 283 & 23 & 85 & 264 \\
\hline & \multirow{3}{*}{ munduk Temu } & \multirow{3}{*}{3} & 105 & 23 & 86 & 264 \\
\hline & & & 389 & 23 & 86 & 264 \\
\hline & & & 306 & 23 & 85 & 244 \\
\hline & \multirow{2}{*}{ jelijih punggang } & \multirow{2}{*}{2} & 310 & 22 & 86 & 264 \\
\hline & & & 319 & 22 & 85 & 264 \\
\hline & \multirow{2}{*}{ Padangan } & \multirow{2}{*}{2} & 316 & 22 & 86 & 302 \\
\hline & & & 313 & 22 & 86 & 304 \\
\hline & & & 306 & 23 & 85 & 264 \\
\hline & Kebon Padangan & 2 & 322 & 23 & 85 & 264 \\
\hline \multirow{10}{*}{$814-1500$} & \multirow{2}{*}{ batungsel } & \multirow{2}{*}{2} & 292 & 22 & 86 & 264 \\
\hline & & & 203 & 22 & 86 & 283 \\
\hline & \multirow{2}{*}{ Blatungan } & \multirow{2}{*}{2} & 356 & 21 & 87 & 244 \\
\hline & & & 344 & 21 & 87 & 244 \\
\hline & \multirow{2}{*}{ Sanda } & \multirow{2}{*}{2} & 283 & 22 & 87 & 283 \\
\hline & & & 272 & 22 & 87 & 264 \\
\hline & \multirow{3}{*}{ Pujungan } & \multirow{3}{*}{3} & 423 & 18 & 90 & 244 \\
\hline & & & 209 & 18 & 90 & 244 \\
\hline & & & 437 & 18 & 90 & 244 \\
\hline & Jumlah & 30 & 9270 & 668 & 2577 & 7815 \\
\hline
\end{tabular}




\begin{tabular}{|c|c|c|c|c|c|c|c|c|c|}
\hline \multicolumn{10}{|c|}{ Paired Samples Test } \\
\hline & & \multicolumn{5}{|c|}{ Paired Differences } & \multirow[t]{3}{*}{$\mathrm{t}$} & \multirow[t]{3}{*}{$\mathrm{df}$} & \multirow{3}{*}{$\begin{array}{l}\text { Sig. (2- } \\
\text { tailed) }\end{array}$} \\
\hline & & \multirow[t]{2}{*}{ Mean } & \multirow[t]{2}{*}{ Std. Deviation } & \multirow[t]{2}{*}{$\begin{array}{l}\text { Std. Error } \\
\text { Mean }\end{array}$} & \multicolumn{2}{|c|}{$\begin{array}{c}\text { 95\% Confidence Interval } \\
\text { of the Difference }\end{array}$} & & & \\
\hline & & & & & Lower & Upper & & & \\
\hline Pair 1 & $\begin{array}{l}\text { Produktivitas - } \\
\text { Suhu Udara }\end{array}$ & 284.848 & 66.305 & 11.542 & 261.338 & 308.359 & 24.679 & 32 & .057 \\
\hline Pair 2 & $\begin{array}{l}\text { Produktivitas - } \\
\text { Kelembaban }\end{array}$ & 222.970 & 65.911 & 11.474 & 199.599 & 246.341 & 19.433 & 32 & .056 \\
\hline Pair 3 & $\begin{array}{l}\text { Produktivitas - } \\
\text { Curah Hujan }\end{array}$ & 45.364 & 73.480 & 12.791 & 19.309 & 71.418 & 3.546 & 32 & .069 \\
\hline & Rata-Rata & & & 9 & 22 & 86 & 261 & & \\
\hline
\end{tabular}

Tabel. 5

Paired Samples Correlations

Sumber: SPSS (Statistical Package For The Social Scinces) 2.1

Tabel 6

Hasil t-tes SPSS

\begin{tabular}{|lccccc|}
\hline & & $\mathrm{N}$ & \multicolumn{2}{c}{ Correlation } & Sig. \\
Pair 1 & Produktivitas \& Suhu Udara & 33 & -.110 & .541 \\
Pair 2 & Produktivitas \& Kelembaban & 33 & .110 & .541 \\
& & & & \\
Pair 3 & Produktivitas \& Curah Hujan & 33 & -.290 & .102 \\
\hline
\end{tabular}

Sumber: SPSS (Statistical Package For The Social Scinces) 2.1

Berdasarkan teknik analisis t-tes yang di lakukan dengan menggunakan SPSS (Statistical Package For The Social Scinces) didapatkan hasil t hitung Suhu udara dengan Produktivitas Kopi Robusta (-24.699), Kelembabanudara dengan Produktivitas Kopi Robusta (-19.371) dan curah hujan dengan Produktivitas Kopi Robusta (3.546). Dengan dilakukan uji dua pihak taraf kesalahan $5 \%$ maka harga $t$ tabel 2,042. Untuk melakukan uji Hipptesis yang telah dibuat maka diperlukan mebandingkan harga $t$ hitung dengan $t$ tabel. Jika harga t hitung lebih kecil dari t tabel maka Ha ditolak dan Ho diterima begitu pula sebaliknya jika t hitung lebih besar dari t tabel maka Ha diterima dan Ho ditolak. Berdasarkan perhitungan $t$ tabel. Pada Tabal 06. Maka diperoleh data sebagai berikut.

1) Suhu Udara dengan Produktivitas Kopi Robusta, t hitung $24.699>$ dari t tabel 2,042 .

2) KelembabanUdara dengan Produktivitas Kopi Robusta, t hitung $19.371>$ dari $t$ tabel 2,042. 
3) Curah Hujan dengan Produktivitas Kopi robusta, t hitung 3.546 >t tabel 2,042.

Dilihat dari data perhitungan t-tes yang dilakukan harga t-tes lebih besar dari $t$ tabel menunjukan bahwa adanya perbedaan antara keadaan iklim mikro dan produktivitas perkebunan Kopi Robusta berdasarkan ketinggian tempat. Tabel 06 menunjukan Ketinggiang tempat belumtentu menentukan tingkat produktivitas perkebunan Kopi Robusta di kecamatan Pupuan, produktivitas terendah terjadi pada ketinggian 700-800 meter diatas permukaan air laut sedangkan pada ketinggian 428628 meter diatas permukaan air laut produktivitasnya tinggi dan pada ketinggian 8141500 diatas permukaan ait laut produktivitastinggi. Namun sebaliknya keadaan iklim mikro berdasarkan ketinggian tempatnya keadaan iklim mikro semakintinggi maka keadaan iklim mikro akan semakin bertambah .

Dilihat dari tingkat korelasinya terdapat hubungan antara iklim mikro dengan produktuvitas kopi robusta dengan taraf signifikan tidak terlalu signifikan pada tabal 05 unsur iklim kelembaban memiliki hubungan positif terhadap produktivitas perkebunan Kopi Robusta di kecamatan pupuan hal ini berkaitan dengan sistem pertanian kopi robusta di Kecamatan pupuan dengan menggunakan sistem pohon penaung atau peneduh dan unsur iklim Suhu udara dan Curah hujan memiliki hubungan negatif terhadap keadaan produktivitas Robusta di Kecamatan Pupuan jika Suhu udara dan Curah hujan meningkat maka keadaan produktivitas menurun. Keadaan iklim mikro di masing-masing tempat juga dipengaruhi oleh periode La-Nina dan Elnino. Hubungan unsur - unsur iklim mikro di kecamatan pupuan tidak terlalu memberikan dampak terhadap perkebunan Kopi Robusta di kecamatan pupuan dikarenakan produktivitas kopi robusta di kecamatan pupuan tidak hanya ditentukan oleh keadaan iklim mikro saja melainkan juaga di pengaruhi oleh faktor lain seperti luas perkebunan, pemeliharaan tanaman, pemupukan dan lain-lainya Penelitian sejenis juga pernah dilakukan oleh (Sihite, Marbun, \& Supriadi, 2015) dengan hasil penelitian , Berdasarkan tabel sidik ragam menunjukkan bahwa hubungan ketinggian tempat terhadap produksi biji merah tidak berpengaruh nyata dimana nilai signifikasi $>$ taraf $5 \%$. Sementara pengaruh ketinggian tempat terhadap jumlah biji merah adalah rendah dengan nilai R 0, 395.

Angka ini disesuaikan dengan penggolongan pengaruh variabel $\mathrm{X}$ terhadap $\mathrm{Y}$ yang didasarkan pada nilai R. Prasetyo et al., (2017) menyatakan; iklim secara umum berpengaruh terhadap produktivitas Kopi Robusta di Kabupaten Malang. Namun hanya suhu yang berhubungan postif terhadap produktivitas Kopi Robusta sedangkan curah hujan dan kelembaban tidak berhubungan nyata. Artinya, apabila terjadi peningkatan suhu maka produktivitas Kopi Robusta akan ikut meningkat selama peningkatan tersebut tidak melebihi batas optimum. Unsur iklim yang paling berpengaruh terhadap produktivitas kopi adalah suhu. Hubungan antara parameter iklim dan produksi perkebunan cukup kompleks, karena faktor lingkungan mempengaruhi pertumbuhan dan perkembangan tanaman dengan bentuk yang berbeda pada tanaman kopi. Faktor iklim lainnya dapat mengurangi produktivitas, seperti suhu udara yang merugikan terjadi selama tahap pertumbuhan yang berbeda. Radiasi matahari dan kelembaban relatif mempengaruhi banyak proses fisiologis dari pohon kopi namun pada umumnya tidak dianggap memainkan peran penting seperti kondisi termal dan curah hujan dalam menentukan potensi hasil atau keterbatasan ekologi untuk tanaman ini (Camargo, 2010).

\section{Simpulan Dan Saran}


Distribusi iklim mikro secara keruangan terdapat di masing-masih desa di kecamatan pupuan dengan klasifikasi menjadi tiga iklim mikro Panas/Tropis, Iklim mikro Sedang dan iklim mikro Sejuk. produktivitas Kopi Robusta di Kecamatan Pupuan terdistribusi secara merata di seluruh desa di Kecamtan Pupuan. Distribusi roduktivitas Kopi robusta secara area atau wilayah terdapat di masing-masing desa. Produktivitas terendah terjadi pada tahun 2014, 2016, 2017, 2008 dan 2010. Peningkatan produktivitas terjadi pada tahun 2012, 2013 dan 2015. Berdasarkan ketinggian tempat keadaan iklim mikro dan produktifitas Kopi robusta memiliki perbedaan. Ketinggian tempat tidak mempengaruhi tingkat produktifitas Kopi robusta di Kecamatan Pupuan. Sedangkan ketinggian Tempat mempengaruhi keadaan iklim mikro di kecamatan pupuan. Berdasarkan ketinggian tempatnya keadaan iklim mikro memiliki hubungan.

Penelitian ini bias dijadikan acuan bahwa ketinggian tempat dan iklim mikro tidak terlalu memberikan dampak terhadap produktivitas perkebuanan Kopi Robusta di Kecamatan Pupuan dan memberikan pemahaman sesuai dengan panca usaha tani yang akan dilakukan.

\section{Daftar Rujukan}

Astawa, I. B. M. (2011). Statistika Terapan. Singaraja: Jurusan Pendidikan Geografi FIS UNDIKSHA.

Banowati, \& Sriyanto. (2013). Geografi Pertanian. Yogyakarta: ombak.

Camargo, marcelo B. de. (2010). The impact of climatic variability and climate change on arabic coffee crop in Brazil. Bragantia, 69 no 1(ISSN 0006-8705).

Prasetyo, S. B., Aini, N., \& Maghfoer, D. (2017). DAMPAK PERUBAHAN IKLIM TERHADAP PRODUKTIVITAS KOPI ROBUSTA (Coffea robusta) DI KABUPATEN MALANG THE EFFECT OF CLIMATE CHANGE ON PRODUCTIVITY ROBUSTA COFFEE ( COFFEA ROBUSTA ) IN MALANG DISTRICT. 5(5), 805-811.

Priantara, I. D. G. Y. dan S. M. (2016). ANALISIS NILAI TAMBAH PENGOLAHAN KOPI ARABIKA KINTAMANIBANGLI. REKAYASA DAN MANJEMEN AGROINDUSTRI, 4(4), $33-42$.

Sihite, L., Marbun, P., \& Supriadi. (2015). Hubungan Ketinggian Tempat Dan Kemiringan Lereng Tehadap Produksi Kopi Arabika Sigarar Utang Di Kecamatan Lintong Nihuta. Vol.3, No.(ISSN No. 2337-6597).

Sriartha, I. P. (2000). Geografi Pertanian. Singaraja: Universitas Pendidikan Ganesha.

Supriadi, H. (2014). Budidaya Tanaman Kopi Untuk Adaptasi dan Mitigasi Perubahan Iklim. Perspektif, 13 no 1(ISSN), 35-52.

Thamrin, S. dan S. H. (2015). Efisiensi Teknis Usahatani Kopi Arabika di Kabupaten Enrekang. Ilmu Pertanian, 18(2), 92-97.

Tjaswono, B. (2004). Klimatologi. bandung: ITB. 